\title{
Rural Women's Access to and Control Over Productive Resources: Implications for Poverty Alleviation Among Osun-State Rural Women, Nigeria
}

\author{
F. O. Adereti \\ Department of Agricultural Extension and Rural Sociology, Faculty of Agriculture, \\ Obafemi Awolowo University, Ile - Ife, Nigeria
}

KEYWORDS Poverty. Control. Resources. Agricultural Activities.

\begin{abstract}
The study focused on the rural women's access to and control over productive resources and the implications of these variables on poverty alleviation among them. The population consisted of all the rural women in Osun State and stratified random sampling technique was used to select the 360 respondents used for the study. Some of the results revealed that a significant relationship existed between poverty alleviating strategies and respondents' access to productive resources such as family members labour $(\mathrm{r}=0.15, \mathrm{p}<0.05)$ and capital $(\mathrm{r}=0.19, \mathrm{p}<0.05)$. it was recommended among others that rural women should be given the opportunity to have access and some degree of control over productive resources in order to alleviate poverty in the rural areas.
\end{abstract}

\section{INTRODUCTION}

It is becoming increasingly difficult for bread winners to provide other basic family needs (apart from food) of housing, clothing, education, health etc for their dependents. Inability to meet these basic needs are indices of poverty which give a sense of non-accomplishment to the bread winner and pre-disposes him to have low self morale, which is a strong index of psychological unwellness. (Sokoya, 1988). The tasks which the rural women are expected to perform and the skills needed to carry them out vary. The African rural woman, like most women must be able to eliminate malnutrition from her family and has the major responsibility of lifting her family out of poverty. Therefore, bearing in mind the enormous roles, which they must perform in order to increase the standard of living of their families, there is the urgent need to look into the rural women's access to and control over productive resources in Osun State.

Nigerian women, perform multiple roles for the survival of their homes and the nation. They constitute a substantial proportion of the Nation's farmers and provide about 60 to 80 percent of the rural labour input (Adekanye, 1988).

Feurstein et al.. (1997) identifies ten types of poverty as follows: inherited poverty, instant poverty, temporary poverty, new poverty, relative poverty, absolute poverty, hidden poverty, endemic poverty, over crowding poverty and terminal poverty. While the gap between the rich and the poor is widening globally, the gap between women and men among the poor is also widening (Sokoya, 1998). Poverty is hitting increasing number of women and it is hitting harder.

Women are the most dis empowered, experiencing inadequate right to land and decision making about its productive use, to decision about water sources to control over the resources they require and there were inequalities in the distribution of food, health care, access to employment opportunities and in women's unequal and declining access to land. (Adekanye, 1988b; World Bank, 1991, 2001; Jazairy, 1992; Agarwal, 1989; Power, 1992). Poorer women have temporary and uncertain access to land, labour, capital and even decision making while better off women and men are more likely to have long term control.

Overall evidence suggests that the scale of poverty in the developing countries continue to worsen despite investments in poverty alleviation (Jazairy and Panuccio, 1992). Today, women have additional work and less assistance and are therefore under greater pressure. It is of special concern that many projects ignore or do not understand this chain of events. The consequence of this is that women are by passed in the development effort, particularly rural women, with harmful consequences to their families. The problem is that the formal means on the poverty alleviation have always been the targets of various projects with insufficient information on the rural women's access to and control over productive resources with respect to solving their 
immediate problems

It is against this background that the study sought answers to the following questions.

1. What are the activities of rural women in Savannah and rain forest regions of Osun State?

2. To what extent do rural women have access to and control over productive resources in rural areas in Osun State?

Purpose of the Study: The general objective of the study was to investigate the rural women's access to and control over productive resources in Osun State. Specially, the study was designed to:

1. identify the demographic characteristics of rural women in Osun State.

2. find out rural women's access to productive resources.

3. investigate the extent of rural women's control over productive resources.

Hypothesis: There is no significant relationship between the access to and control of rural women to productive resources and poverty alleviation strategies in Osun State.

\section{METHODOLOGY}

The Target Population, Sample and Sampling Procedure: The target population for the study comprised all rural women in Osun State, Nigeria. Stratified random sampling technique was used in the selection of the respondents. The thirty Local Government Areas (LGAs) available in the state were stratified into two that is those in the derived savanna zone of the state and the rain forest zone from which three LGAs were randomly selected from each group. There were a total of 15 LGAs in each group in which 3 LGAs were selected to represent each zone. A total of 6 LGAs were finally selected. The first 3 LGAs were in the derived savanna region which includes Irepodun, Ifelodun and Odo-Otin LGAs while the remaining 3 LGAs were in the forest zone which includes Atakumosa West, Ayedaade and Irewole LGAs of the state. The areas that were considered rural were the settlements that had between 100 and 200 households. Ten settlements were selected from each of the LGAs and finally 6 rural women were selected as respondents from each of the ten settlements in each LGA. To this end, 60 rural women were selected as respondents from each LGA in all, a total of 360 rural women participated in the study. The breakdown of the respondents is as shown in appendix 1

Instrument: Questionnaire was the instrument used. Both face and content validity of the instrument were carried out. The reliability of the instrument on the other hand was then conducted using test-retest method and the reason for doing this was to have the stability of the instrument determined. This procedure resulted in reliability coefficient of (r) 0.82 .

Data Analysis: Descriptive and inferential statistics were employed in the analysis of the data collected.0 Pearson Moment Correlation was used for testing the hypothesis stated.

\section{RESULT AND DISCUSSION}

i. Demographic Variables: This is shown in table 1. The actual ages of the respondents were

Table 1: Demographic Variables/characteristics of rural women in Osun State

\begin{tabular}{|c|c|c|}
\hline Variables & Frequency & Percentage \\
\hline \multicolumn{3}{|l|}{ A. Age (in years) } \\
\hline Less than 20 & 01 & 0.3 \\
\hline $21-24$ & 23 & 6.4 \\
\hline $25-25$ & 28 & 7.8 \\
\hline $30-34$ & 54 & 15 \\
\hline $35-39$ & 66 & 18.3 \\
\hline $40-44$ & 73 & 20.3 \\
\hline $45-49$ & 53 & 14.7 \\
\hline $50-54$ & 37 & 10.3 \\
\hline $55-59$ & 18 & 5.0 \\
\hline 60 and above & 07 & 1.9 \\
\hline Total & 360 & 100 \\
\hline \multicolumn{3}{|l|}{ B. Marital Status } \\
\hline i. Single & 47 & 13.1 \\
\hline ii. Married & 263 & 73.0 \\
\hline iii. Widowed & 32 & 8.9 \\
\hline iv. Divorced & 18 & 5.0 \\
\hline Total & 360 & 100 \\
\hline \multicolumn{3}{|l|}{ C. Religion } \\
\hline 1. Christians & 263 & 73 \\
\hline 2. Muslims & 90 & 25 \\
\hline 3. Traditional & 7 & 2 \\
\hline Total & 360 & 100 \\
\hline \multicolumn{3}{|l|}{ D. Education } \\
\hline 1. No formal education & 112 & 31.1 \\
\hline 2. Adult Education & 26 & 7.2 \\
\hline 3. Some primary & 27 & 7.5 \\
\hline 4. Finished primary & 45 & 12.5 \\
\hline 5. Some secondary & 40 & 11.1 \\
\hline 6. Finished secondary & 32 & 8.9 \\
\hline 7. Vocational education & 36 & 10.0 \\
\hline 8. Others & 42 & 11.7 \\
\hline Total & 360 & 100 \\
\hline
\end{tabular}

Source: Field Survey 2000. 
considered and grouped into ten categories. The results showed that most of the respondents (68.3 percent) were between the ages of 30 and 49 years. This implies that majority of the rural women in the sampled areas were young adults. This actually forms the active period in their lives in which they can still be fully involved in performing the roles expected of them in the family.

On the marital status, the result showed that majority of them were married (73\%). Also, the study revealed that 7.2 percent had adult education while 21.1 percent had no formal education, which might be due to financial constraint of the rural women.

On the issue of religion, most of them were Christians ( 73 percent) this is significant because the type of work that can be done by the Christian women may differ form that of the Muslim women. Muslim rural women may not be allowed to go out and perform specific activities in the area of agriculture such as piggery or even field work.

Table 2: Distribution of respondents by income generating activities.

\begin{tabular}{|c|c|c|c|c|c|c|c|}
\hline \multirow{2}{*}{\multicolumn{2}{|c|}{ Variables }} & \multicolumn{2}{|c|}{$\begin{array}{c}\text { Types of } \\
\text { activities }\end{array}$} & \multicolumn{2}{|c|}{$\begin{array}{c}\text { Fully } \\
\text { involved }\end{array}$} & \multicolumn{2}{|c|}{$\begin{array}{c}\text { Occasionally } \\
\text { never }\end{array}$} \\
\hline & & $F$ & $\%$ & $F$ & $\%$ & $F$ & $\%$ \\
\hline i. & $\begin{array}{l}\text { Planting } \\
\text { of crops }\end{array}$ & 212 & 58.9 & 114 & 31.7 & 34 & 9.4 \\
\hline ii. & $\begin{array}{l}\text { Rearing } \\
\text { of annuals }\end{array}$ & 96 & 26.7 & 208 & 57.7 & 56 & 15.6 \\
\hline iii. & $\begin{array}{l}\text { Livestock } \\
\text { selling }\end{array}$ & 73 & 20.3 & 198 & 55.0 & 89 & 24.7 \\
\hline iv. & $\begin{array}{l}\text { Petty } \\
\text { trading }\end{array}$ & 95 & 26.4 & 190 & 52.9 & 75 & 20.8 \\
\hline v. & $\begin{array}{l}\text { Craft } \\
\text { weaving }\end{array}$ & 17 & 4.7 & 116 & 32.2 & 226 & 62.8 \\
\hline vi. & $\begin{array}{l}\text { Hired } \\
\text { casual } \\
\text { labour }\end{array}$ & 83 & 23.1 & 144 & 40 & 133 & 36.9 \\
\hline vii. & $\begin{array}{l}\text { Hair } \\
\text { plaiting }\end{array}$ & 65 & 18.1 & 158 & 43.9 & 137 & 38.1 \\
\hline & $\begin{array}{l}\text { Native } \\
\text { doctor }\end{array}$ & 13 & 3.6 & 54 & 15.0 & 293 & 81.9 \\
\hline ix. & $\begin{array}{l}\text { Crop } \\
\text { processing }\end{array}$ & 167 & 46.4 & 138 & 38.3 & 55 & 15.3 \\
\hline $\mathrm{x}$. & $\begin{array}{l}\text { Gathering } 2 \\
\text { and selling } \\
\text { non- timber } \\
\text { forest produ }\end{array}$ & 219 & 60.8 & 86 & 23.9 & 55 & 15.3 \\
\hline xi. & $\begin{array}{l}\text { Selling of } \\
\text { cooked foods }\end{array}$ & $\mathrm{ds}^{38}$ & 10.6 & 135 & 37.5 & 187 & 1.9 \\
\hline & $\begin{array}{l}\text { Serving \& } \\
\text { knitting }\end{array}$ & - & - & 105 & 29.2 & 225 & 70.8 \\
\hline xiii. & Pottery & 10 & 2.8 & 87 & 24.2 & 263 & 73.0 \\
\hline xiv. & Carving & - & - & 66 & 18.3 & 294 & 81.7 \\
\hline & Others & 4 & 1.1 & 262 & 72.7 & 94 & 26.2 \\
\hline
\end{tabular}

ii. Income Generating Activities of Rural Women: Table 2 depicts the findings of the distribution of respondents by income generating activities.

The respondents gave multiple responses and this implies that they were involved in more than one activity in most cases as coping strategies. Many of the rural women were involved in planting of crops (58.9\%). Crop processing (46.4\%), gathering and selling of Non-Timber Forest Products (NTFPs) $(60.8 \%)$. The women were only partially involved in sewing and knitting (29.2\%) and carving (18.3\%). This therefore accounted for their multiple responses in which they were involved in other agricultural activities. Only a handful of the rural women engaged in craft weaving and pottery. Only 3.6 percent of the respondents involved themselves in native medicine. This development might be due to the fact that most of them were Christians and only a small proportion of them were traditionalists. Also, many of them were occasionally involved in the rearing of animals $(57.7 \%)$, petty trading $(52.9 \%)$ and livestock selling (55\%), hired casual labour (40\%), hair plaiting $(43.9 \%)$ and selling of cooked foods(37.5\%). Olawoye (1985) and Adekanye (1988a) were in support of these findings when they concluded that women constituted a substantial proportion of the nations farmers and provided about 60 to 80 percent of the rural labour input, though in different degrees in agricultural production.

iii. Rural Women's Access and Control Over Productive Resources: The result in Table 3 revealed that the respondents did not have absolute control over most of the productive resources. Like land, capital (formal sources), mechanized equipment, chemicals of various type. However they had absolute control over personal labour (64.4\%), family members' labour $(16.7 \%)$ informal sources of capital $(46.4 \%)$ and simple farm tools $(66.4 \%)$. It was revealed also that they had short term access in the following areas land $(45.3 \%)$, family members' labour (56.7\%); chemicals viz fertilizers $(47.8 \%)$; pesticides (38.3\%) and Herbicides (41.9\%). In a similar vein, 54.7 percent of the respondents did not have access to even family members' labour; and $52.2 \%, 61.7 \%$ and $58.1 \%$ of them did not have access to fertilizers, pesticides and Herbicides respectively. In a nutshell none of them has absolute control over land and 
Table 3: Distribution of respondents by access to and control over productive resources.

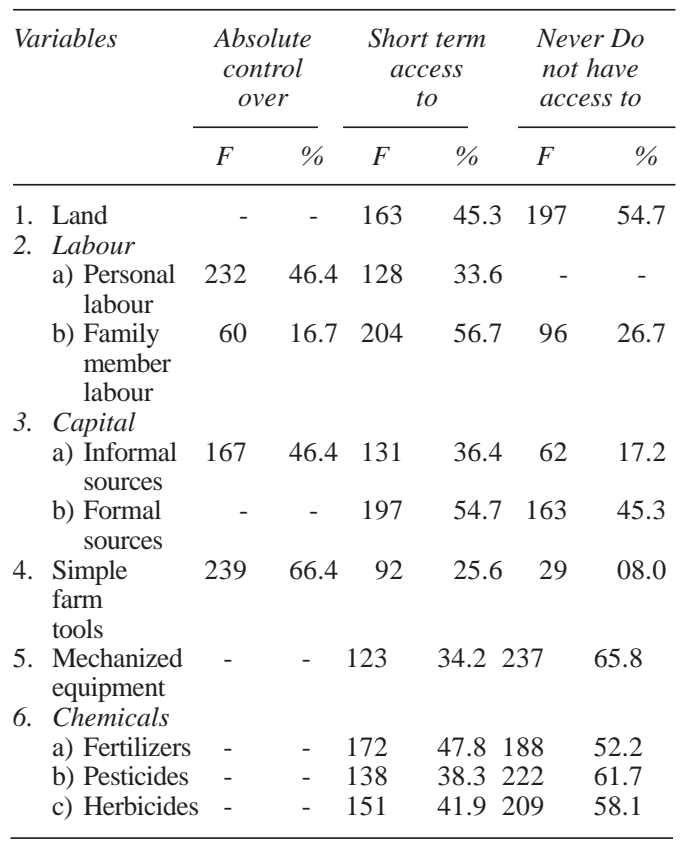

mechanized equipment, formal sources of capital and chemicals. This is a clear indication that they are handicapped in performing well in the productive sector. Jazairy 1992, Power 1992 and Agarwal, 1989 supported the findings in which Jazairy 1992 opined that in many places, women were not allowed to own land and control family finances.

\section{Testing of Hypothesis}

(a) Hypothesis 1: The results in table 4 shows

Table 4: Correlation analysis showing the relationship between resources and respondents access to poverty alleviation strategies in Osun State.

\begin{tabular}{|c|c|c|c|c|}
\hline & Variables & $r$. & $p$. & Decision \\
\hline i. & Land & 0.03 & 0.06 & Not significant \\
\hline ii. & Personal labour & -0.09 & 0.09 & Not Significant \\
\hline iii. & $\begin{array}{l}\text { Family members } \\
\text { labour }\end{array}$ & 0.15 & 0.004 & Significant \\
\hline iv. & Informal source & 0.19 & 0.00 & Significant \\
\hline v. & formal sources & 0.01 & 0.85 & Not significant \\
\hline vi. & Simple farm tools & 0.27 & 0.00 & Significant \\
\hline vii. & $\begin{array}{l}\text { Mechanized } \\
\text { equipment }\end{array}$ & -0.05 & 0.39 & Not significant \\
\hline viii. & Fertilizer & 0.06 & 0.23 & Not significant \\
\hline ix. & Pesticides & 0.02 & 0.97 & Not significant \\
\hline $\mathrm{x}$. & Herbicides & -0.06 & 0.23 & Not significant \\
\hline
\end{tabular}

non-perfect positive relationship in which $\mathrm{p}$ values were less than 0.05 and the correlation coefficient stood between 0 and less than +1 . Negative correlation also existed in some of the variables however; no perfect negative correlation was obtained since there was no case where -1.00 was recorded. It can therefore be concluded that in verse but significant relationships exist between access to productive resources and poverty alleviating strategies in some of the variables such as family members labour $\mathrm{r}=0.15$, $\mathrm{p}<0.05$; simple farm tools $\mathrm{r}=$ $0.27 ; \mathrm{p}<0.05$. However, the relationship was not significant in variables such as land $\mathrm{r}=0.03$ $\mathrm{p}>0.05$; personal labour $\mathrm{r}=-0.09$; $\mathrm{p}>0.05$; mechanized equipment $\mathrm{r}=-0.05 ; \mathrm{p}>0.05$. The reason for this occurrence might be due to the present state of the poor rural women in terms of their access to the productive resources which is not encouraging.

The inability of the rural women to have access to productive resources such as land, in rural areas and the unavailability of alternative sources of income determine the persistence of chronic poverty among potentially productive groups (World Bank, 1991). In support of these findings also, Agarwal (1989) and power (1992) submitted that there were inequalities in the distribution of food, health care and access to employment opportunities and in women's unequal and declining access to land.

\section{Implications for Poverty Alleviation}

In the area of the demographic variable, since most of the respondents fell between the ages of 30 and 49, this implies that the respondents are still in their active period of their lives. They still possess the ability of engaging in various agricultural activities, which will go a long way in solving their immediate food needs.

Their marital status is also a pointer to the fact that meeting household responsibilities will be a joint effort of both the husband and the wife, their low level of education might also contribute significantly to their inability to adopt innovations in poverty reduction strategies. There is need therefore to increase their educational awareness.

Higher percentage recorded in the area of religion in favour of Christianity implies that the respondents might engage in diverse agricultural activities such as piggery, which Muslims 
might decide not to be involved in. Such activities can reduce poverty amongst rural women. In the aspect of income generating activities, the rural women were involved in multiple income generating activities, which shows that they have their own initiatives in meeting household food needs. The implication of this is that efforts should be made to improve upon these strategies so that, the problem of meeting household food needs will be reduced to a greater extent.

On the area of access to and control over productive resources, the results clearly showed that none of the respondents had absolute control over land, mechanized equipment, formal sources of capital and chemicals. Since they are handicapped in all these productive resources, it implies that their efforts in reducing poverty may prove abortive, as these variables are all inevitable.

The non-perfect positive relationship recorded in the hypothesis tested was a clear indication that without these productive resources nothing tangible can be achieved in their efforts to minimize poverty among women folks. The rural women take initiatives to improve their own standard of living based on the level of services available to them. The policy implication of this for extension in Nigeria is the need for Government, Non-Governmental Organizations to recognize and improve on these initiatives by setting up community development associations and village development committees. This development will assist these rural women in their efforts to come out of poverty.

\section{CONLUSIONAND RECOMMENDATIONS}

A number of conclusions can be drawn from the major findings. Age accounted for the ability of the rural women to be involved in various activities. It could therefore be inferred that younger rural women of less than 20 years and those that are over 60 years may not have the full strength of being involved actively in various agricultural activities. Also, middle aged rural women are likely to perform better than much older ones and younger ones too. This tends to justifiably conform to the trend that the extent of activities to be involved in tends to decrease as an individual's age increases.

The most important income generating activities of these rural women as revealed were crop farming, livestock rearing and few indicated other income generating activities. There appears to be preference for the choice of the activities that they could engage in. It can be concluded that these activities are not on large scale which might be attributed to their inability of having access to the productive resources as expected. Also, non-access to and control over productive resources account for the present predicament of the rural women and their ability to meet up with their family needs. Non-availability of these productive resources would not enable them to meet up with their responsibilities in poverty alleviation.

Based on the results of the study, the following recommendations are made:

1. There is need to increase the extent of the access of rural women to productive resources in order to enable them perform their roles in poverty alleviation effectively.

2. Efforts should be made by individuals, philanthropists, Governments at Local, State and Federal levels to make provision for the improvement of productive resources as well as increase the access of rural women to productive resources as this will improve the quality of their lives.

3. There is need to increase the level of awareness of the rural populace to the significance of education since the level of education determines the rate of adoption of innovation in the productive sector.

4. There is the need to source for additional income generating activities particularly for the poorer rural women which will eventually assist the poor rural women to have additional income in this present unfavourable economic condition.

\section{REFERENCES}

Adekanye, T.O.: Women in African agriculture. African Notes, Journal of the Institute of African Studies. University of Ibadan,Special Issue, No. 3: 1-8 (1988a).

Adekanye, T.O.: Women and rural poverty: some considerations from Nigeria. African Notes. Special Issue, No. 3: 6367 (1988b).

Agarwal, B.: Rural women, poverty and natural resources, sustenance, sustainability and struggle for change. Economic and Political Weekly, India, 24(43): 46-65 (1989).

Feurstein, Marie-Theresa: Poverty and Health: Reaping A Richer Harvest. Macmillan Publishers, Hongkong (1997).

Jazairy, I.M, Alamgir and Pannuccio, T.: The State of the World Rural Poverty. An Inquiry into its Causes and 
Consequences. Intermmediate Technology Publications, London (1992).

Olawoye, J.E.: Rural women's role in agricultural production. An occupational survey of women from six selected rural communities in Oyo State, Nigeria. Journal of Rural Sociology, 2(1): 34 - 36 (1985).

Power, J.: The Report of Rural Women Living in Poverty. International Fund for Agricultural Development, Rome (1992).

Sokoya, G.O.: Poverty and psychological well- being of farm families: implications for rural extension. Nigerian Journal of Applied Psychology, 4(1): 123-134 (1998).

World Bank Report Nigeria: Strategies for food and Nutrition. Security Report Number, 9040 UNI (1991):

World Bank Report: World Development Indicators. World Bank, Washington, D.C. (2000).

\section{APPENDIX 1}

Composition of the sample based on the Local Government Areas.

\begin{tabular}{cllc}
\hline Area & $\begin{array}{c}\text { Local } \\
\text { Government } \\
\text { area }\end{array}$ & $\begin{array}{c}\text { Head- } \\
\text { quarter }\end{array}$ & $\begin{array}{c}\text { Number of } \\
\text { respon- } \\
\text { dents }\end{array}$ \\
\hline $\begin{array}{c}\text { Rain Forest Region } \\
1\end{array}$ & Atakumosa West & Osu & 60 \\
2 & Ayedaade & Gbongan & 60 \\
3 & Irewole & Ikire & 60 \\
Savanna Region & Irepodun & Ikirun & 60 \\
4 & Odo-Otin & Okuku & 60 \\
5 & Ifelodun & Ilobu & 60 \\
6 & & & 360 \\
\hline Total & & &
\end{tabular}

